\title{
ВПЛИВ КРАНІОСКЕЛЕТНОЇ ТРАВМИ, УСКЛАДНЕНОЇ КРОВОВТРАТОЮ, НА АКТИВНІСТЬ ПРОЦЕСІВ ЦИТОЛІЗУ ТА ЕНДОГЕННОЇ ІНТОКСИКАЦІЇ В РАННІЙ ПЕРІОД У ЩУРІВ 3 РІЗНОЮ РЕЗИСТЕНТНІСТЮ ДО ГІПОКСІЇ
}

Вступ. Травматизм на сьогодні вважають однією з актуальних проблем сучасного урбанізованого суспільства. У його структурі домінують тяжкі множинні та поєднані ураження, які нерідко ускладнюються поліорганною недостатністю, що стає безпосередньою причиною смерті постраждалих. У роботах багатьох авторів показано, що в основі системних порушень за умов травматичної хвороби лежить посилення процесів цитолізу та ендотоксикозу. Недостатньо вивченим залишається фрормування синдрому цитолізу та ендотоксикозу при краніоскелетній травмі у тварин з різною конституційною стійкістю до гіпоксії.

Мета дослідження - з'ясувати динаміку маркерів цитолізу та ендотоксикозу за умов краніоскелетної травми, ускладненої крововтратою, у щурів з різною резистентністю до гіпоксії в ранній період травматичної хвороби.

Методи дослідження. Експерименти виконано на 148 нелінійних білих щурах-самцях масою 180-200 г, які перебували на стандартному раціоні віварію. Попередньо у тварин визначили індивідуальну стійкість до гіпоксії та виділили 2 групи: високо- і низькостійких (BC, НС). У щурів моделювали краніоскелетну травму та поєднували їі з гострою крововтратою. Через 1, 3 і 7 діб у сироватці крові й печінці різностійких до гіпоксії тварин визначали активність аланінамінотрансферази (АлАT) та вміст фрракції молекул середньої маси, визначених при довжині хвилі 280 нм (МСM 280$)$.

Результати й обговорення. У патогенезі краніоскелетної травми вагоме місце займає розвиток синдрому цитолізу та ендотоксикозу, що проявляється підвищенням у сироватці крові активності цитоплазматичного ензиму АлАТ та вмісту орракції MCM $_{280}$, яка відображає появу ароматичних амінокислот як результат порушеного метаболізму. Встановлено, що у НС тварин виявлені порушення були більшими. За умов додаткового моделювання гострої крововтрати в межах 20-22 \% об'єму циркулюючої крові у групах НС і ВС щурів відмічали поглиблення процесів цитолізу та ендотоксикозу, особливо через 3-7 діб експерименту. При цьому порушення активності АлАТ та вмісту фрракції $\mathrm{MCM}_{280}$ у сироватці крові ВС тварин були істотно меншими, ніж у НС щурів.

Висновок. За умов моделювання краніоскелетної травми у НС щурів посилення процесів цитолізу та ендотоксикозу є більшим, ніж у групі ВС тварин. Порушення у НС щурів поглиблюються при додатковому моделюванні гострої крововтрати.

КЛЮЧОВІ СЛОВА: краніоскелетна травма; крововтрата; стійкість до гіпоксії; аланінамінотрансфераза; молекули середньої маси.

ВСТУП. Травматизм на сьогодні вважають однією з актуальних проблем сучасного урбанізованого суспільства. У його структурі домінують високоенергетичні травми, які зумовлюють тяжкі множинні та поєднані ураження. Незважаючи на значні успіхи в наданні медичної допомоги травмованим, часто результати такого лікування залишаються незадовільними. Основною їх причиною є розвиток у пацієнтів травматичної хвороби, яка нерідко ускладнюється поліорганною недостатністю, що стає безпосередньою причиною смерті постраждалих. Поглиблене

() Д. О. Сікіринська, А. А. Гудима, І. Я. Господарський, К. А. Походун, 2021. вивчення патогенезу поліорганної недостатності та розробка патогенетично обґрунтованих заходів корекції дотепер залишаються невиконаним завданням сучасної медицини $[1,2]$.

У роботах багатьох авторів показано, що в основі системних порушень за умов травматичної хвороби лежить активація пероксидного окиснення ліпідів і білків клітинних мембран тканин та органів 3 порушенням мембранозалежних метаболічних процесів, збільшенням їх проникності й формуванням синдрому цитолізу та ендогенної інтоксикації, що замикає чергове "хибне коло", яке поглиблює синдром поліорганної недостатності [3, 4]. 
На сьогодні доведено, що експериментальна крані оскелетна травма супроводжується посиленням процесів ліпідної пероксидації, виснаженням антиоксидантного захисту, збільшенням вмісту в крові маркерів цитолізу та ендотоксикозу, поглибленням дисорункції внутрішніх органів, зокрема печінки [5]. Проте залишається недостатньо вивченим фрормування синдрому цитолізу та ендотоксикозу за умов краніоскелетної травми у тварин з різною конституційною стійкістю до гіпоксії, складовою якої $€$ баланс активності про- та антиоксидантних систем організму [4].

Мета дослідження - з'ясувати динаміку маркерів цитолізу та ендотоксикозу за умов краніоскелетної травми, ускладненої крововтратою, у щурів з різною резистентністю до гіпоксії в ранній період травматичної хвороби.

МЕТОДИ ДОСЛІДЖЕННЯ. Експерименти виконано на 148 нелінійних білих щурах-самцях масою 180-200 г, які перебували на стандартному раціоні віварію. Попередньо за методикою, описаною в роботі [6], у щурів визначили індивідуальну стійкість до гіпоксії та виділили 2 групи: високо- і низькостійких до гіпоксії (ВС, НС) тварин. Через 14 днів ВС і НС тварин поділили на 3 групи: контрольну (по 6 інтактних щурів) та 2 дослідних (по 68 щурів). За умов тіопентал-

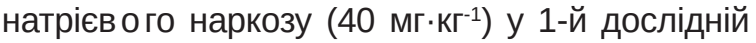
групі моделювали краніоскелетну травму шляхом послідовного нанесення дозованого удару по черепу з досягненням закритої черепно-мозкової травми середнього ступеня тяжкості та дозованого удару по стегну ударним пристроєм з клиноподібною насадкою з досягненням закритого перелому стегна [7]. У 2-й дослідній групі за умов асептики й антисептики додатково моделювали гостру крововтрату в обсязі 20-22 \% об'єму циркулюючої крові шляхом пересікання стегнової вени [8].

Тварин в иводили з експерименту за умов використання наркозу через 1, 3 і 7 діб посттравматичного періоду. Для дослідження брали сироватку крові, в якій визначали активність аланінамінотрансферази (АлАТ) уніфрікованим методом для аналізатора біохімічного "Humalyzer 2000" та вміст фрракції молекул середньої маси, визначених при довжині хвилі 280 нм $\left(\mathrm{MCM}_{280}\right)$ [9], поява якої вказує на тяжке порушення метаболізму з посиленням синтезу ароматичних амінокислот і є важливим індикатором розвитку поліорганної диссрункції [10].

Розраховували абсолютні величини досліджуваних показників, а також відношення індивідуальних величин до середньої величини контрольної групи, що пов'язано з різним рівнем активності досліджуваних біохімічних маркерів у ВС і НС щурів контрольної групи.

Статистичний аналіз отриманих результатів проводили з використанням критерію Манна Уїтні у програмному пакеті STATISTICA 10.0 ("StatSoft, Inc.", США).

РЕЗУЛЬТАТИ Й ОБГОВОРЕННЯ. ЯК ВИДНО з таблиці 1, у контрольній групі у ВС тварин активність АлАТ у сироватці крові була статистично вірогідно більшою, ніж у НС щурів (на 13,0 \%, p<0,05). Внаслідок краніоскелетної травми активність АлАТ у сироватці крові, порівняно 3 контролем, зростала в обох дослідних групах 3 максимумом через 3 доби експерименту: в НС щурів - у 2,4 раза, у ВС тварин - на 58,3 \% $(\mathrm{p}<0,05)$. До 7-ї доби показник знижувався порівняно 3 попереднім терміном спостереження (відповідно, на 16,6 та 15,0 \%, p<0,05), проте продовжував залишатись істотно вищим, ніж у контрольній групі (відповідно, у 2,0 рази і на $34,6 \%, p<0,05)$. Порівняння НС і ВС тварин із краніоскелетною травмою показало, що активність у сироватці крові ВС тварин АлАТ у всі терміни експерименту була статистично вірогідно меншою, ніж у НС щурів (відповідно, на 22,5, 25,5 та 24,1\%, p<0,05).

За умов додаткової крововтрати в обох дослідних групах активність АлАТ теж зростала. У групі НС щурів показник, порівняно з контролем, досягав знову ж максимуму через 3 доби (у $2,83$ раза, $p<0,05)$ і залишався на такому ж рівні до 7-ї доби. У групі ВС тварин він теж досягав максимуму через 3 доби (у 2,12 раза, $р<0,05$ ), проте до 7-ї доби знижувався, що було статистично вірогідно меншим порівняно з 3-ю добою (на 12,3 \%, p<0,05). Порівняння НC і ВС щурів із краніоскелетною травмою, ускладненою крововтратою, показало, що активність АлАТ у сироватці крові була істотно меншою у групі ВС тварин (відповідно, на 12,3, 15,4 та 25,5 \%, $p<0,05)$.

Аналіз впливу гострої крововтрати на динаміку активності АлАТ у сироватці крові за умов краніоскелетної травми показав, що у НС щурів при гострій крововтраті показник через 3 і 7 діб був статистично вірогідно більшим, ніж у тварин цієї ж дослідної групи без крововтрати (відповідно, на 18,1 та 40,7 \%, p $\left._{1}<0,05\right)$. У ВС тварин за умов моделювання додаткової крововтрати активність АлАТ у всі терміни спостереження була істотно вищою, ніж у ВС щурів без гострої крововтрати (відповідно, на 23,1, 34,1 та 38,0 \%, $\left.\mathrm{p}_{2}<0,05\right)$.

Аналіз середнього відношення індивідуальних величин активності АлАТ до середньої величини контрольної групи у відповідь на краніо- 
Таблиця 1 - Динаміка активності аланінамінотрансферази у сироватці крові $\left(\mathrm{O}_{\mathrm{A}} \boldsymbol{л}^{-1}\right)$ у відповідь на краніоскелетну травму, ускладнену крововтратою, у тварин з різною стійкістю до гіпоксії (Me (LQ; UQ)) - медіана (нижній і верхній квартилі)

\begin{tabular}{|c|c|c|c|c|}
\hline \multirow{2}{*}{$\begin{array}{l}\text { Стійкість } \\
\text { до гіпоксії }\end{array}$} & \multirow{2}{*}{ Контроль } & \multicolumn{3}{|c|}{ Термін посттравматичного періоду } \\
\hline & & 1-ша доба & 3-тя доба & 7-ма доба \\
\hline \multicolumn{5}{|c|}{ Краніоскелетна травма } \\
\hline Низькостійкі & $\begin{array}{c}66,80 \\
(61,50 ; 69,85) \\
(n=6)\end{array}$ & $\begin{array}{c}120,8^{\star} \\
(110,6 ; 125,7) \\
(n=7)\end{array}$ & $\begin{array}{c}160,4^{\star 1 A} \\
(152,5 ; 165,9) \\
(n=7)\end{array}$ & $\begin{array}{c}133,8^{\star 1 д, 3 д} \\
(131,6 ; 140,5) \\
(n=7)\end{array}$ \\
\hline Високостійкі & $\begin{array}{c}75,50^{\#} \\
(74,65 ; 78,00) \\
(n=6)\end{array}$ & $\begin{array}{c}93,60^{\star \#} \\
(93,88 ; 95,45) \\
(n=8)\end{array}$ & $\begin{array}{c}119,5^{\star \# 1 д} \\
(113,2 ; 124,4) \\
(n=10)\end{array}$ & $\begin{array}{c}101,6^{\star \# 1 д, з д} \\
(98,8 ; 111,5) \\
(n=10)\end{array}$ \\
\hline \multicolumn{5}{|c|}{ Краніоскелетна травма+крововтрата } \\
\hline Низькостійкі & $\begin{array}{c}66,80 \\
(61,50 ; 69,85) \\
(n=6)\end{array}$ & $\begin{array}{c}131,4^{*} \\
(126,0 ; 134,2) \\
(n=6)\end{array}$ & $\begin{array}{c}189,4^{\star 1 A} \\
(182,9 ; 197,8) \\
(n=6)\end{array}$ & $\begin{array}{c}188,2^{\star 1 д} \\
(185,6 ; 190,4) \\
(n=5)\end{array}$ \\
\hline Високостійкі & $\begin{array}{c}75,50^{\#} \\
(74,65 ; 78,00) \\
(n=6)\end{array}$ & $\begin{array}{c}115,2^{\star \#} \\
(112,4 ; 118,7) \\
(n=8)\end{array}$ & $\begin{array}{c}160,2^{\star \# 1 д} \\
(154,6 ; 164,8) \\
(n=9)\end{array}$ & $\begin{array}{c}140,2^{\star \# 1 д, з д ~} \\
(133,7 ; 142,8) \\
(n=8)\end{array}$ \\
\hline \multicolumn{2}{|c|}{$\mathrm{p}_{1}$} & $>0,05$ & $<0,05$ & $<0,05$ \\
\hline \multicolumn{2}{|c|}{$\mathrm{p}_{2}$} & $<0,05$ & $<0,05$ & $<0,05$ \\
\hline
\end{tabular}

Примітки. Тут і в таблицях 2-4:

1. * - відмінності стосовно контрольної групи статистично вірогідні $(p<0,05)$.

2. \# - відмінності між групами ВС і НС тварин статистично вірогідні $(p<0,05)$.

3. 1д,зд - відмінності стосовно 1-ї і 3-ї діб спостереження статистично вірогідні $(p<0,05)$.

4. $\mathrm{p}_{1}$ - вірогідність відмінностей у групах НС тварин з наявною та відсутньою додатковою крововтратою.

5. $\mathrm{p}_{2}$ - вірогідність відмінностей у групах ВС тварин з наявною та відсутньою додатковою крововтратою.

скелетну травму показав (табл. 2), що у ВС тварин у всі терміни спостереження показник був статистично вірогідно меншим, ніж у групі НС щурів (відповідно, на 29,3, 31,2 та 32,5 \%, р<0,05). У групі тварин із краніоскелетною травмою, ускладненою крововтратою, активність АлАТ теж у ВС щурів виявилась істотно нижчою, ніж у НС тварин, у всі терміни спостереження (відповідно, на 22,3, 25,4 та 34,0 \%, р<0,05).

Аналіз рівня ендогенної інтоксикації, який ми оцінювали за вмістом у сироватці крові фрракції $\mathrm{MCM}_{280}$, показав (табл. 3), що в контрольній групі відмічали більшу величину досліджуваного показника у НС щурів порівняно з ВС тваринами, однак результат виявився статистично не значущим ( $p>0,05)$. За умов моделювання лише краніоскелетної травми у групі НС щурів він поступово зростав з 1-ї до 7-ї доби посттравматичного періоду й у всі терміни спостереження був істотно вищим, ніж у контрольній групі (відповідно, на 21,7 \%, у 2,13 та 2,56 раза, р<0,05). Аналогічною була динаміка досліджуваного показника й у групі ВС тварин (відповідно, на $27,5,82,5 \%$ та у 2,35 раза, $p<0,05)$. Порівняння

\begin{abstract}
Таблиця 2 - Динаміка середнього відношення індивідуальних величин активності аланінамінотранссрерази до середньої величини контрольної групи у відповідь на краніоскелетну травму, ускладнену крововтратою, у тварин з різною стійкістю до гіпоксії (Me (LQ; UQ)) - медіана (нижній і верхній квартилі)
\end{abstract}

\begin{tabular}{|c|c|c|c|}
\hline \multirow{2}{*}{ Стійкість до гіпоксії } & \multicolumn{3}{|c|}{ Термін посттравматичного періоду } \\
\hline & 1-ша доба & 3-тя доба & 7-ма доба \\
\hline \multicolumn{4}{|c|}{ Краніоскелетна травма } \\
\hline Низькостійкі & $\begin{array}{c}1,81 \\
(1,66 ; 1,88) \\
(n=7)\end{array}$ & $\begin{array}{c}2,40 \\
(2,28 ; 2,48) \\
(n=7)\end{array}$ & $\begin{array}{c}2,00 \\
(1,97 ; 2,10) \\
(n=7)\end{array}$ \\
\hline Високостійкі & $\begin{array}{c}1,28^{\#} \\
(1,24 ; 1,32) \\
(n=8) \\
\end{array}$ & $\begin{array}{c}1,58^{\#} \\
(1,50 ; 1,65) \\
(n=10)\end{array}$ & $\begin{array}{c}1,35^{\#} \\
(1,31 ; 1,48) \\
(n=10) \\
\end{array}$ \\
\hline \multicolumn{4}{|c|}{ Краніоскелетна травма+крововтрата } \\
\hline Низькостійкі & $\begin{array}{c}1,97 \\
(1,89 ; 2,01) \\
(n=7)\end{array}$ & $\begin{array}{c}2,84 \\
(2,74 ; 2,96) \\
(n=7)\end{array}$ & $\begin{array}{c}2,82 \\
(2,78 ; 2,85) \\
(n=7)\end{array}$ \\
\hline Високостійкі & $\begin{array}{c}1,53^{\#} \\
(1,49 ; 1,57) \\
(n=8)\end{array}$ & $\begin{array}{c}2,12^{\#} \\
(2,05 ; 2,18) \\
(n=10)\end{array}$ & $\begin{array}{c}1,86^{\#} \\
(1,77 ; 1,89) \\
(n=10)\end{array}$ \\
\hline
\end{tabular}


Таблиця 3 - Динаміка вмісту фракції молекул середньої маси, визначених при довжині хвилі 280 нм (ум. од.), у відповідь на краніоскелетну травму, ускладнену крововтратою, у тварин з різною стійкістю до гіпоксії (Me (LQ; UQ)) - медіана (нижній і верхній квартилі)

\begin{tabular}{|c|c|c|c|c|}
\hline \multirow{2}{*}{$\begin{array}{l}\text { Стійкість } \\
\text { до гіпоксії }\end{array}$} & \multirow{2}{*}{ Контроль } & \multicolumn{3}{|c|}{ Термін посттравматичного періоду } \\
\hline & & 1-ша доба & 3-тя доба & 7-ма доба \\
\hline \multicolumn{5}{|c|}{ Краніоскелетна травма } \\
\hline Низькостійкі & $\begin{array}{c}0,046 \\
(0,045 ; 0,048) \\
(n=6)\end{array}$ & $\begin{array}{c}0,056^{\star} \\
(0,054 ; 0,059) \\
(n=7)\end{array}$ & $\begin{array}{c}0,098^{* 1 A} \\
(0,092 ; 0,104) \\
(n=7)\end{array}$ & $\begin{array}{c}0,118^{\star 1 д, 3 д} \\
(0,117 ; 0,121) \\
(n=7)\end{array}$ \\
\hline Високостійкі & $\begin{array}{c}0,040 \\
(0,035 ; 0,045) \\
(n=6)\end{array}$ & $\begin{array}{c}0,051^{*} \\
(0,050 ; 0,053) \\
(n=8)\end{array}$ & $\begin{array}{c}0,073^{\star \# 1 д} \\
(0,062 ; 0,078) \\
(n=10)\end{array}$ & $\begin{array}{c}0,093^{* \# 1 д, з д} \\
(0,082 ; 0,100) \\
(n=10)\end{array}$ \\
\hline \multicolumn{5}{|c|}{ Краніоскелетна травма+крововтрата } \\
\hline Низькостійкі & $\begin{array}{c}0,046 \\
(0,045 ; 0,048) \\
(n=6)\end{array}$ & $\begin{array}{c}0,071^{\star} \\
(0,067 ; 0,076) \\
(n=6)\end{array}$ & $\begin{array}{c}0,123^{\star 1 A} \\
(0,116 ; 0,131) \\
(n=6)\end{array}$ & $\begin{array}{c}0,146^{\star 1 д, 3 д} \\
(0,146 ; 0,148) \\
(n=5)\end{array}$ \\
\hline Високостійкі & $\begin{array}{c}0,040 \\
(0,035 ; 0,045) \\
(n=6)\end{array}$ & $\begin{array}{c}0,063^{\star} \\
(0,062 ; 0,067) \\
(n=8)\end{array}$ & $\begin{array}{c}0,088^{\star \# 1 д} \\
(0,086 ; 0,096) \\
(n=9)\end{array}$ & $\begin{array}{c}0,110^{\star \# 1 д, з д ~} \\
(0,102 ; 0,123) \\
(n=8)\end{array}$ \\
\hline \multicolumn{2}{|c|}{$p_{1}$} & $<0,05$ & $<0,05$ & $<0,05$ \\
\hline \multicolumn{2}{|c|}{$\mathrm{p}_{2}$} & $<0,05$ & $<0,05$ & $<0,05$ \\
\hline
\end{tabular}

дослідних груп між собою показало статистично вірогідно менший вміст МСМ $_{280}$ у сироватці крові ВС щурів через 3 і 7 діб експерименту (відповідно, на 25,5 та 21,3\%, p<0,05).

Моделювання краніоскелетної травми в поєднанні з гострою крововтратою, порівняно 3 контролем, теж призводило до збільшення вмісту фрракції МCM $_{280}$ в обох дослідних групах: у НС тварин - відповідно, на 54,3 \%, у 2,67 та 3,17 раза ( $p<0,05)$, у ВС щурів - відповідно, на 57,5 \%, у 2,2 і 2,75 раза $(p<0,05)$. Порівняння дослідних груп дозволило встановити менший вміст фрракції $\mathrm{MCM}_{280}$ у сироватці крові ВС тварин порівняно 3 НС щурами, що виявилося статистично значущим через 3 і 7 діб експерименту (відповідно, на 42,2 та 24,6 \%, p<0,05).
Аналіз впливу гострої крововтрати на вміст фрракції $\mathrm{MCM}_{280}$ у сироватці крові за умов краніоскелетної травми у НС тварин показав, що в усі терміни експерименту наявність додаткової крововтрати супроводжувалася вищим показником (відповідно, на 26,8, 25,5 та 23,7\%, $\mathrm{p}_{1}<0,05$ ). Аналогічно більшим виявився вміст у ВС тварин із краніоскелетною травмою, яким додатково моделювали гостру крововтрату (відповідно, на $23,5,20,5$ та $\left.18,3 \%, p_{2}<0,05\right)$.

Аналіз динаміки середнього відношення індивідуальних величин вмісту фрракції $\mathrm{MCM}_{280} \mathrm{y}$ сироватці крові до середньої величини контрольної групи у відповідь на краніоскелетну травму показав (табл. 4), що у ВС тварин показник через 3 доби експерименту був істотно меншим, ніж у

Таблиця 4 - Динаміка середнього відношення індивідуальних величин вмісту фракції молекул середньої маси, визначених при довжині хвилі 280 нм, у сироватці крові до середньої величини контрольної групи у відповідь на краніоскелетну травму, ускладнену крововтратою, у тварин з різною стійкістю до гіпоксії (Me (LQ; UQ)) - медіана (нижній і верхній квартилі)

\begin{tabular}{||c|c|c|c|}
\hline \multirow{2}{*}{ Стійкість до гіпоксії } & \multicolumn{3}{|c|}{ Термін посттравматичного періоду } \\
\cline { 2 - 4 } & 1-ша доба & 3-тя доба & 7-ма доба \\
\hline Низькостійкі & \multicolumn{2}{|c|}{ Краніоскелетна травма } & 2,57 \\
& $(1,17 ; 1,22$ & 2,13 & $(2,54 ; 2,63)$ \\
& $(\mathrm{n}=7)$ & $(2,00 ; 2,26)$ & $(\mathrm{n}=7)$ \\
\hline Високостійкі & 1,28 & $(\mathrm{n}=7)$ & 2,31 \\
& $(1,24 ; 1,33)$ & $1,85^{\#}$ & $(2,06 ; 2,50)$ \\
& $(\mathrm{n}=8)$ & $(1,55 ; 1,95)$ & $(\mathrm{n}=10)$ \\
\hline & Краніоскелетна травма+крововтрата & $(\mathrm{n}=10)$ & 3,17 \\
& 1,54 & 2,67 & $(3,17 ; 3,22)$ \\
& $(1,45 ; 1,64)$ & $(2,51 ; 2,84)$ & $(\mathrm{n}=5)$ \\
\hline Низькостійкі & $(\mathrm{n}=6)$ & $2,6)$ & $2,74^{\#}$ \\
& 1,58 & $(2,15 ; 2,40)$ & $(2,54 ; 3,08)$ \\
& $(1,54 ; 1,66)$ & $(\mathrm{n}=9)$ & $(\mathrm{n}=8)$ \\
\hline
\end{tabular}


НС щурів (на 13,4 \%, p<0,05). В інші терміни експерименту відмінності між групами порівняння були статистично не вірогідними ( $>>0,05)$. За умов додаткової крововтрати досліджуваний показник теж виявився істотно нижчим у групі ВС тварин, що було статистично значущим через 3 і 7 діб експерименту (відповідно, на 25,9 та $13,6 \%, p<0,05)$.

Отримані результати свідчать про те, що в патогенезі краніоскелетної травми вагоме місце займає розвиток синдрому цитолізу та ендотоксикозу, що проявляється підвищенням у сироватці крові активності цитоплазматичного ензиму АлАТ та вмісту фракції $\mathrm{MCM}_{280}$, яка відображає появу ароматичних амінокислот як результат порушеного метаболізму. Подібні результати одержали й інші автори [5]. Вони свідчать про виражені системні порушення внаслідок нанесення травми й ураження органів, віддалених від місця безпосереднього травмування, зокрема печінки - основного органа детоксикації організму. Отримані порушення відповідають основним засадам концепції “травматичної хвороби" [11].

Однак ми вперше встановили, що у НС тварин виявлені порушення були більшими. Враховуючи той фракт, що пусковим чинником посилення проникності клітинних мембран та порушення мембранозалежних фрункцій є їх деструкція внаслідок переокиснення мембранних ліпідів і білків активними фрормами оксигену та його метаболітами під впливом краніоскелетної травми, можна припустити, що в основі виявлених порушень лежить більша інтенсифрікація прооксидантних механізмів на тлі недостатності антиоксидантного захисту. Саме цим принципово відрізняються ВС і НС тварини, що показано в роботах ряду авторів [12]. Тому подібна реакція, імовірно, є конституційно закріпленою і свідчить про нижчу резистентність НС щурів до патогенних чинників травматичної хвороби.

Підтвердженням цього припущення є поглиблення процесів цитолізу та ендотоксикозу за умов додаткового моделювання гострої крововтрати в межах 20-22 \% об'єму циркулюючої крові. За даних обставин поглиблюється гіпоксія, посилюється активація лейкоцитів у вогнищі ураження, що призводить до ще більшого синтезу активних форм оксигену і його мембранодеструктивної дії [13]. Це підтвердилося поглибленням у групах НС і ВС тварин процесів цитолізу та ендотоксикозу, особливо через 3-7 діб експерименту. Однак і за даних обставин порушення активності АлАТ і вмісту фрракції MCM $_{280}$ у сироватці крові ВС тварин було істотно меншим, ніж у НС щурів.

Таким чином, організм НС і ВС тварин $є$ нерівнозначним до впливів патогенних чинників травматичної хвороби, які стосуються впливу на проникність клітинних мембран та порушення клітинного метаболізму. Отримані результати свідчать про вагоме діагностичне і прогностичне значення більшого зростання у травмованих активності АлАТ та вмісту фрракції MCM $_{280}$ як результат не тільки тяжкості травми, але й нижчої резистеності організму, що вимагає інтенсивнішої терапії і подальшого поглибленого доклінічного дослідження.

ВИСНОВКИ. 1. Основними відмінностями НС та ВС щурів контрольної групи є статистично вірогідно більша активність у сироватці крові АлАТ і тенденція до зменшення вмісту фрракції $\mathrm{MCM}_{280}$ у ВС тварин.

2. За умов моделювання краніоскелетної травми у НС щурів посилення процесів цитолізу та ендотоксикозу більше, ніж у ВС тварин. Порушення у НС щурів поглиблюються при додатковому моделюванні гострої крововтрати.

Перспективи подальших досліджень. У перспективі на основі розроблених моделей травматичної хвороби доцільно дослідити ефективність різноманітних субстанцій 3 антиоксидантними властивостями у низько- і високостійких до гіпоксії тварин.

\section{СПИСОК ЛІТЕРАТУРИ}

1. Гур'єв С. О. Аналіз безпосередіх причин смерті у постраждалих із політравмою та пошкодженням скелета / С. О. Гур'єв, А. Ю. Філь, О.М.Танасієнко // Травма. - 2015. - 16, № 4. - С. 7-10.

2. Філь А. Ю. Хірургічна концепція лікування постраждалих із політравмою у гострому періоді / А. Ю. Філь // Травма. - 2014. - 15, № 5. - С. 20-23.
3. Козак Д. В. Динаміка показників цитолізу в умовах політравми / Д. В. Козак // Шпитальна хірургія. - 2012. - № 2 (58). - С. 50-52.

4. Михайлюк I. А. Динаміка показників цитолізу в умовах раннього періоду травматичної хвороби після скелетної, черепно-мозкової травми та їх поєднання / І. А. Михайлюк, А. А. Гудима, В. М. Михайлюк // Вісн. наук. дослідж. - 2015. - № 1. - С. 120-122. 
5. Борис Р. М. Морфологічні і біохімічні зміни внутрішніх органів при експериментальній краніоскелетній травмі : монограсрія / Р. М. Борис. - Тернопіль : THMУ, 2013. - 142 c.

6. Сатурська Г. С. Особливості метаболізму сполучної тканини при експериментальному дифузному ішемічно-некротичному кардіосклерозі у щурів із різною стійкістю до гіпоксії / Г. С. Сатурська, Ю. І. Бондаренко // Вісн. ВНМУ. - 2014. - 18, № 2. - С. 425-429.

7. Борис Р. М. Динаміка показників пероксидного окиснення ліпідів у період ранніх і пізніх проявів травматичної хвороби за умов експериментальної краніоскелетної травми та її корекції клітинною терапією / Р. М. Борис, А.І. Гоженко, А. А. Гудима // Клініч. та експерим. патологія. -2013. - 12, № 2 (44). - С. 31-34.

8. Influence of two-hour tourniquets ischemia of limb and acute blood loss on systemic disorders of the body in the reperfusion period (experimental study) / I. I. Horban, A. A. Hudyma, R. V. Maksymiv, I. V. Antonyshyn // Wiad. Lek. - 2020. - LXXIII, Iss. 7. - P. 1330-1333.

9. Методи дослідження ендогенної інтоксикації організму : метод. рек. / М. А. Андрейчин, М. Д. Бех, В. В. Дем'яненко [та ін.] ; Мін-во охорони здоров'я

\section{REFERENCES}

1. Huryev, S.O., Fil, A.Yu., \& Tanasiyenko, O.M. (2015). Analiz bezposeredikh prychyn smerti u postrazhdalykh iz politravmoiu ta poshkodzhenniam skeleta [Analysis of direct causes of death in victims with polytrauma and skeletal damage]. Travma - Trauma, 16 (4), 7-10 [in Ukrainian].

2. Fil, A.Yu. (2014). Khirurhichna kontseptsiia likuvannia postrazhdalykh iz politravmoiu u hostromu periodi [Surgical concept of treatment of victims with polytrauma in the acute period]. Travma - Trauma, 15, 5, 20-23 [in Ukrainian].

3. Kozak, D.V. (2012). Dynamika pokaznykiv tsytolizu $\checkmark$ umovakh politravmy [Dynamics of cytolysis indices in the conditions of polytrauma]. Shpytalna khirurhiia Hospital Surgery, 2 (58), 50-52 [in Ukrainian].

4. Mykhailiuk, I. A., Hudyma, A.A., \& Mykhailiuk, V.M. (2015). Dynamika pokaznykiv tsytolizu v umovakh rannoho periodu travmatychnoi khvoroby pislia skeletnoi, cherepno-mozkovoi travmy ta yikh poiednannia [Dynamics of the cytolysis in the conditions of the early period of the traumatic disease after skeletal, cranial-cerebral trauma and their combination]. Visnyk naukovykh doslidzhen - Bulletin of Scientific Research, 1, 120-122 [in Ukrainian].

5. Borys, R.M. (2013). Morfolohichni i biokhimichni zminy vnutrishnikh orhaniv pry eksperymentalnii kranioskeletnil travmi: monohrafiia [Morphological and biochemical changes of internal organs at experimental cranioskeletal trauma: monograph]. Ternopil: Ukrmedknyha [in Ukrainian].

6. Saturska, H.S., \& Bondarenko, Yu.I. (2014). OsobIyvosti metabolizmu spoluchnoi tkanyny pry eksperymentalnomu dyfuznomu ishemichno-nekrotychnomu kar-
України, Укр. центр наук. мед. інформації та патентно-ліцензійної роботи. - К., 1998. - 33 с.

10. Зяблицев С. В. Механизмы и ключевые звенья развития синдрома эндогенной интоксикации при черепно-мозговой травме / С. В. Зяблицев, С. Я. Коровка, П. А. Чернобривцев // Міжнар. вісн. медицини. 2013. - 6, № 1. - С. 18-23.

11. Патофизиология травмы (обзор экспериментального коллективного исследования проблемы за 40 лет) / В. Н. Ельский, С. В. Зяблицев, Ю. Я. Крюк [и др.] // Вісн. морфрології. - 2015. - 21, № 1. - С. $242-$ 251.

12. Взаимозависимость показателей свободнорадикального окисления в печени и крови у крыс с разной устойчивостью к гипоксии после перенесенной аноксии / Г. А. Байбурина, Е. А. Нургалеева, С. А. Башкатов, Д. 3. Шибкова // Казан. мед. журн. - 2015. - 96, № 5. - С. 798-802.

13. Крилюк В. О. Розвиток синдрому ендогенної інтоксикації за умов поєднаної травми органів черевної порожнини на фоні гіповолемічного шоку та реперфузійного синдрому кінцівки / В. О. Крилюк, Г. Ю. Цимбалюк // Вісн. наук. дослідж. - 2018. № 2 (91). - С. 145-149. diosklerozi u shchuriv iz riznoiu stiikistiu do hipoksii [Features of the connective tissue metabolism in experimental diffuse ischemic necrotic cardiosclerosis in rats with different resistance to hypoxia]. Visnyk VNMU - Bulletin VNMU, 18 (2), 425-429 [in Ukrainian].

7. Borys, R.M., Gozhenko, A.I., \& Hudyma, A.A. (2013). Dynamika pokaznykiv peroksydnoho okysnennia lipidiv u period rannikh i piznikh proiaviv travmatychnoi khvoroby za umov eksperymentalnoi kranioskeletnoi travmy ta yii korektsii klitynnoiu terapiieiu [The dynamics of lipid peroxidation indices during early and late manifestations of traumatic disease under conditions of experimental cranioskeletal injury and its correction by cell therapy]. Klinichna ta eksperymentalna patolohiia Clinical and Experimental Pathology, KHII, 2 (44), 31-34 [in Ukrainian].

8. Horban, I.I., Hudyma, A.A., Maksymiv, R.V., \& Antonyshyn, I.V. (2020). Influence of two-hour tourniquets ischemia of limb and acute blood loss on systemic disorders of the body in the reperfusion period (experimental study). Wiad. Lek., LXXIII, 7, 1330-1333.

9. Andreichyn, M.A., Bekh, M.D., \& Demianenko, V.V. (1998). Metody doslidzennia endohennoi intoksykatsii orhanizmu: metodychni rekomendatsii [Methods of study of endogenous intoxication of an organism: methodical recommendations]. Ministry of Health of Ukraine. Ukrainian Centre of Scientific Medical Information and Patent-License Work. Kyiv [in Ukrainian].

10. Zyablitsev, S.V., Korovka, S.Ya., \& Chernobrivtsev, P.A. (2013). Mekhanizmy i klyuchevyye zvenya razvitiya sindroma endogennoy intoksikatsii pri cherepnomozgovoy travme [Mechanisms and key links in the development of endogenous intoxication syndrome in 
traumatic brain injury]. Mizhnarodnyi visnyk medytsyny International Journal of Medicine, 6, 1, 18-23 [in Russian].

11. Jelski, V.N., Zyablitsev, S.V., Kruck, Yu.Y., Krivobok, G.K., Zolotuhin, S.E., Kolesnikova, S.V., ..., \& Strelchenko, I.I. (2015). Patofiziologiya travmy (obzor eksperimentalnogo kollektivnogo issledovaniya problemy za 40 let) [Trauma pathophysiology (40 years collective experimental review)]. Visnyk morfolohii - Bulletin of Morphology, 21, 1, 242-251 [in Ukrainian].

12. Bayburina, G.A., Nurgaleeva, E.A., Bashkatov, S.A., \& Shibkova, D.Z. (2015). Vzaimozavisimost pokazateley svobodnoradikalnogo okisleniya $v$ pecheni i krovi u krys s raznoy ustoychivostyu k gipoksii posle perenesonnoy anoksii [Association of blood and liver free radical oxidation indicators in rats with different resistance to hypoxia after survived anoxia]. Kazanskiy meditsinskiy zhurnal - Kazan Medical Journal, 96, 5, 798-802 [in Russian].

13. Krylyuk, V.O., \& Tsymbaliuk, H.Yu. (2018). Rozvytok syndromu endohennoi intoksykatsii za umov poiednanoi travmy orhaniv cherevnoi porozhnyny na foni hipovolemichnoho shoku ta reperfuziinoho syndromu kintsivky [Development of endogenic intoxication syndrome after combine trauma of abdominal cavity with hypovolemic shock and reperfusion syndrome of limb]. Visnyk naukovykh doslidzhen - Bulletin of Scientific Research, 2 (91), 145-149 [in Ukrainian].

\section{ВЛИЯНИЕ КРАНИОСКЕЛЕТНОЙ ТРАВМЫ, ОСЛОЖНЕННОЙ КРОВОПОТЕРЕЙ, НА АКТИВНОСТЬ ПРОЦЕССОВ ЦИТОЛИЗА И ЭНДОГЕННОЙ ИНТОКСИКАЦИИ В РАННИЙ ПЕРИОД У КРЫС С РАЗНОЙ РЕЗИСТЕНТНОСТЬЮ К ГИПОКСИИ}

\section{Резюме}

Вступление. Травматизм на сегодня считают одной из актуальных проблем современного урбанизированного общества. В его структуре доминируют тяжелые множественные и сочетанные поражения, которые нередко осложняются полиорганной недостаточностью, что становится непосредственной причиной смерти пострадавших. В работах многих авторов показано, что в основе системных нарушений в условиях травматической болезни лежит усиление процессов цитолиза и эндотоксикоза. Недостаточно изученным остается фрормирование синдрома цитолиза и эндотоксикоза при краниоскелетной травме у животных с разной конституционной устойчивостью к гипоксии.

Цель исследования - выяснить динамику маркеров цитолиза и эндотоксикоза в условиях краниоскелетной травмы, осложненной кровопотерей, у крыс с разной резистентностью к гипоксии в ранний период травматической болезни.

Методы исследования. Эксперименты выполнены на 148 нелинейных белых крысах-самцах массой 180-200 2, которые находились на стандартном рационе вивария. Предварительно у животных определили индивидуальную устойчивость к гипоксии и выделили 2 группы: высоко- и низкоустойчивых (ВУ, НУ). У крыс моделировали краниоскелетную травму и сочетали ее с острой кровопотерей. Через 1, 3 и 7 суток в сыворотке крови и печени разностойких к гипоксии животных определяли активность аланинаминотрансфреразы (АлАТ) и содержание фрракции молекул средней массы, определенных при длине волны 280 нм $\left(\mathrm{MCM}_{280}\right)$.

Результаты и обсуждение. В патогенезе краниоскелетной травмы важное место занимает развитие синдрома цитолиза и эндотоксикоза, что проявляется повышением в сыворотке крови активности цитоплазматического энзима АлАТ и содержания фрракции MCM $_{280}$, которая отражает появление ароматических аминокислот как результат нарушенного метаболизма. Установлено, что в НУ животных выявленные нарушения были большими. В условиях дополнительного моделирования острой кровопотери в пределах 20-22 \% объема циркулирующей крови в группах НУ и ВУ животных отмечали углубление процессов цитолиза и эндотоксикоза, особенно через 3-7 суток эксперимента. При этом нарушения активности АлАТ и содержания фрракции MCM $_{280}$ в сыворотке крови ВУ животных были существенно меньше, чем в НУ крыс.

Вывод. В условиях моделирования краниоскелетной травмы в НУ крыс усиление процессов цитолиза и эндотоксикоза является большим, чем в группе ВУ животных. Нарушения в НУ крыс углубляются при дополнительном моделировании острой кровопотери.

КЛЮЧЕВЫЕ СЛОВА: краниоскелетная травма; кровопотеря; устойчивость к гипоксии; аланинаминотранссераза; молекулы средней массы. 
D. A. Sikirinskaya, A. A. Hudyma, I. Ya. Hospodarsky, K. A. Pokhodun I. HORBACHEVSKY TERNOPIL NATIONAL MEDICAL UNIVERSITY

\title{
EFFECT OF CRANIOSKELETAL TRAUMA COMPLICATED WITH BLOOD LOSS ON THE ACTIVITY OF CYTOLYSIS AND ENDOGENOUS INTOXICATION IN THE EARLY PERIOD IN RATS WITH DIFFERENT HYPOXIA RESISTANCE
}

\begin{abstract}
Summary
Introduction. Injuries are now considered one of the pressing problems of modern urban society. Its structure is dominated by severe multiple and combined lesions, which are often complicated by multiple organ failure, which becomes the direct cause of death. The work of many authors has shown that the basis of systemic disorders in traumatic illness is the strengthening of cytolysis and endotoxicosis. The formation of cytolysis and endotoxicosis syndrome under conditions of cranioskeletal trauma in animals with different constitutional resistance to hypoxia remains insufficiently studied.
\end{abstract}

The aim of the study - to determine the dynamics of markers of cytolysis and endotoxicosis in cranioskeletal trauma complicated by blood loss in rats with different resistance to hypoxia in the early period of traumatic illness.

Research Methods. The experiments were performed on 148 nonlinear white male rats weighing 180-200 g, which were on the standard diet of the vivarium. Previously, individual resistance to hypoxia was determined in rats and two groups were identified: high- and low-resistant (HR, LR). In animals, cranioskeletal trauma was simulated and combined with acute blood loss. After 1, 3, and 7 days, the activity of alanine aminotransferase (ALT) and the content of middle mass molecules determined at a wavelength of $280 \mathrm{~nm}\left(\mathrm{MMM}_{280}\right)$ were determined in the serum of the liver of animals resistant to hypoxia.

Results and Discussion. In the pathogenesis of cranioskeletal trauma an important place is occupied by the development of cytolysis syndrome and endotoxicosis, which is manifested by an increase in serum activity of the cytoplasmic enzyme ALT and MMM $M_{280}$ fraction, which reflects the appearance of aromatic amino acids as a result of impaired metabolism. It was found that in emergencies before hypoxia of animals detected violations are greater. Under the conditions of additional modeling of acute blood loss in the range of 20-22\% of the circulating blood volume in the groups of LR and HR of animals, deepening of cytolysis and endotoxicosis processes was noted, especially after 3-7 days of the experiment. Under these conditions, the violation in the serum of ALT activity and the content of the $M M M_{280}$ fraction in the group of animals was significantly less than in the animals.

Conclusion. Under the conditions of modeling of cranioskeletal trauma in the emergency to hypoxia of animals, the intensification of cytolysis and endotoxicosis is greater than in the group of animals. Disorders in the emergency of animals are exacerbated by additional modeling of acute blood loss.

KEY WORDS: cranioskeletal trauma; blood loss; resistance to hypoxia; alanine aminotransferase; middle mass molecules.

Отримано 10.03.21

Адреса для листування: Д. О. Сікіринська, Тернопільський начіональний медичний університет імені І. Я. Горбачевського мОз України, майдан Волі, 1, тернопіль, 46001, Україна, e-mail: sikirynskado@tdmu.edu.ua. 